\title{
Web Usability Evaluation Based on Eye Tracking. Case Study of Lithuanian National Museum Website
}

\author{
Andrius Šuminas \\ Media Research Lab, Vilnius University \\ Arūnas Gudinavičius \\ Media Research Lab, Vilnius University
}

\begin{abstract}
Purpose/thesis: The aim of the research paper is to outline web usability evaluation based on eye tracking and to determine the usability of the website of the National Museum - Palace of the Grand Dukes of Lithuania from the user perspective in the process of searching for the most required information.

Approach/methods: A literature analysis was used to get acquainted with usability evaluation methods and the historical review of visual attention studies. Questionnaire based interviews with visitors of the museums were used to collect information about people information needs and searching patterns on museum websites. In order to evaluate the website of the National Museum - Palace of the Grand Dukes of Lithuania the researchers used eye tracking equipment.

Results and conclusions: The eye tracking have recently gained attention in different research areas, however issues of museum website design and usability research using eye tracking techniques and methods have not been widely discussed in scientific literature so far.

The research on the information needs of the visitors of Lithuanian museum websites revealed the most required information: opening hours, museum location, entrance ticket price and information about exhibitions. The results confirmed the assumption that people used museum websites as a primary tool to prepare for a visit at the physical museum.

The eye tracking analysis of the website of the National Museum - Palace of the Grand Dukes of Lithuania revealed the typical mistakes and errors made in information placement. When the information most needed by the users is placed in different parts and levels of the website, the visitors have to spend more time and effort to find the information and to prepare for a visit at the museum. Originality/value: Issues of the museum websites design are not widely discussed in worldwide scientific literature. There are no data about eye tracker based research on museum websites done in Lithuania before. The analysis results may contribute to new knowledge about designing successful interfaces for museum websites. Moreover, the results could be used in a broader field to improve the interfaces and information representation for websites in general.
\end{abstract}

\section{Keywords}

Web usability. Eye Tracking. Museum websites. Information needs.

Received: 13.02.2015. Revised:02.06.2015. Accepted: 12.06.2015. 


\section{Defining Web Usability}

The rapid development of Internet technology brings the changes in the form of interaction of all institutions and companies with their users and visitors. The significance of website design is growing as it serves two purposes: to interact with stakeholders and to create a positive image of the company. It explains the increasing focus on the topic of website usability. Although different definitions of usability have been proposed to this day, in the general sense, it refers to the quality of products and systems from the point of view of humans who use them. According to ISO 9241-11 (Ergonomic Requirements for Office Work with Visual Display Terminals) recommendation, which became the standard for the usability specialist community, it is defined as:

the extent to which a product can be used by specified users to achieve specified goals with effectiveness, efficiency and satisfaction in a specified context of use (ISO, 1998).

Jakob Nielsen, who is widely quoted for formulating the main parameters describing the rules of usability, defines it as:

a quality attribute that assesses how easy user interfaces are to use. The word "usability" also refers to methods for improving ease-of-use during the design process (Nielsen, 2012).

The five components which describe usability are: learnability, efficiency, memorability, errors, and satisfaction. Matera and colleagues (2006) refined those parameters to capture the specificity of web applications. Their interpretation of the rules proposed by Nielsen is as follows:

1. Web application learnability must be interpreted as the ease for Web users to understand from Home Page the contents and services made available through the application, and how to look for specific information using the available links for hypertext browsing. Learnability also means that each page in the hypertext front-end should be composed in a way so as contents are easy to understand and navigational mechanisms are easy to identify.

2. Web applications efficiency means that users that want to find some contents can reach them quickly through the available links. Also, when users get to a page, they must be able to orient themselves and understand the meaning of the page with respect to their navigation starting point.

3. Memorability implies that, after a period of non-use, users are still able to get oriented within the hypertext, for example by means of navigation bars pointing to landmark pages.

4. Few errors mean that in case users have erroneously followed a link, they should be able to return to their previous location.

5. Users' satisfaction finally refers to the situation in which users feel that they are in control with respect to the hypertext, thanks to the comprehension of available contents and navigational commands.

Accessibility is another important concept regarding usability - it focuses on those properties of websites which allow for the access of any class of users using any type of technology. When websites are correctly designed and developed, all users have equal access to information and functionality. The task of preparing the guidelines of accessibility was performed by the Web Accessibility Initiative (WAI) which developed WCAG 2.0: a technical standard. It has 12 guidelines that are organized under four principles: perceivable, operable, understandable, and robust. 


\section{Usability Evaluation Methods}

Although the aforementioned technical standards are very important for high level usability, they are insufficient for a complex website evaluation. Thus, there is a wide array of usability evaluation methods which cover the diversity of the issue. Matera and colleagues (2006) distinguished two main broad categories of the evaluation method which refers to the stage of design process: formative evaluation, which takes place during design, and summative evaluation, which occurs after the product is developed. Evaluation methods may also be classified according to the way of data collection. User testing methods are intended to conduct the studies with real users; usability inspection involves the specialists who assess the product in the process and Web usage analysis is also to obtain the data about user behavior but based on the analysis of Web access logs. Among those three classes there are different techniques which allow to picture different characteristics of websites. User testing may be performed by using, i.e. think aloud protocol, remote usability testing or eye tracking. Among usability inspection methods the most commonly used are heuristic evaluation (Nielsen, 1993; Nielsen \& Mack, 1994) in which usability specialists judge whether application properties conform to the established usability principles and cognitive walkthrough (Polson et al., 1992; Wharton et al., 1994). Web usage analysis may include only the analysis of simple traffic statistics which allow to identify the most accessed pages and contents but do not describe user navigation patterns on the website. They may be observed by means of different extensions of Web logging mechanisms, i.e. Web Usage Mining techniques (Cooley, 2003). The choice of particular methods depends on the purpose of the evaluation as they have their advantages and disadvantages. For more details the reader is referred to Matera and colleagues (2006) where those methods are described and compared.

\section{Visual Attention Studies: Historical Review}

The eye tracking techniques have recently gained attention in the website usability research as a technique which may reflect cognitive processing through eye movement metrics among human physiological parameters, eye movement has the most frequent period of update. The phenomena of visual attention have been studied for over a century. In the beginning they were conducted on the basis of observation. In his books, Edmund Huey described the works of Luis Javal as one of the first researchers interested in this area (Huey, 1908). In 1879 the French scientist noted the actual character of eye movement in reading: a series of short stops (called fixations) and quick saccades rather than a smooth sweeping of the eyes along the text as it was previously assumed. Huey built one of the first eye tracking machines using a kind of contact lens and an aluminum pointer attached to them, which reacted to eye movement. It allowed him to prove that some words in a sentence are not fixated. The early research was also conducted by van Helmholtz (1925) who was interested in essential mechanisms of visual perception, in particular a link between eye movements and the spatial location of the object. Gibson (1941) checked how the viewer's expectation influenced by the experimenter's instructions influences his perception and reactions. The early research was not only related to book reading and picture watching schemas. In 1947 Fitts and colleagues studied the movements of pilots' eyes as they used 
cockpit controls and instruments to land an airplane (Fitts et al., 1950). According to Jacob and Karn:

this study represents the earliest application of eye tracking to what is now known as usability engineering - the systematic study of users interacting with products to improve product design (Jacob \& Karn, 2003, 574).

Another important eye tracking research study was conducted by Yarbus (1967) who analyzed the relations between the tasks given to the viewer and his way to analyze the pictures seen. He stated that the pattern of eye movements

is dependent not only on what is shown on the picture, but also on the problem facing the observer and the information that he hopes to gain from the picture. (Yarbus, 1967, 194)

Yarbus' eye movement records demonstrated sequential viewing patterns over particular regions on the picture. The research studies quoted above are only few examples of works conducted in this field. For a more detailed description of the early research the reader is referred to Duchowski (2007, 3-13), van der Heijden (1991, 1-63) or Jacob and Karn (2003, 574-577).

\section{Eye Tracking in Different Research Areas}

Increasing attention to the research using eye tracking techniques is closely connected to technical development. Jakob Nielsen described the problems pertaining to early-stage eye tracking research in this way:

In the old days, eyetracking was done by truly tortuous means, such as physically gluing something to a test subject's eyeballs. (...) In addition to knowing how the eye is turning within the socket, you need one more piece of information to calculate where the person is looking: where the head is. The first eyetrackers we used in the 1980s solved this problem by strapping the user's head into a fixed position. In doing this, they eliminated the need to calculate where the head was because it always was in the same spot. This was not a very pleasant experience for test participants, however (Nielsen \& Pernice, 2009, 4).

Nowadays, when the eye tracking equipment does not cause any discomfort, this technique has become widely used. The growing number of studies using eye tracking is clearly visible in the analysis of the results of the query performed in the Web of Science. The search for the articles which contain the words 'eye tracking' as keywords or in a title resulted in 4822 records (the query was performed in the Web of Science Core Collection on 28 Nov. 2014). The growth of interest in this topic is seen when comparing the amount of articles in the following years: in 2013 - 634 articles (13\% of all registered publications) were found in the database compared to only 74 articles in 2000 (1.5\% of all publications). It is also interesting to check the research areas, where eye tracking techniques is used: it is most commonly applied in psychology research (33\%), computer science (22\%), engineering (14\%) and neuroscience neurology (14\%) (see Tab. 1). A deeper analysis of results reflects the diversity of eye tracking applications as transportation, library science, zoology, etc. 
are mentioned among research areas. As it was pointed out by Senders (2000), the use of eye tracking has persistently come back to solve new problems in each decade since the 1950s which is illustrated by the number and diversity of publications. Moreover, the presented summary includes only scientific publications while the eye tracking technique is commonly used in market research.

Table 1. The results of the query: TOPIC ("eye tracking" or eyetracking or eye-tracking)

OR TITLE: ("eye tracking" or eyetracking or eye-tracking) conducted in the Web of Science Core Collection (28.11.2014) sorted by research areas

\begin{tabular}{|l|c|c|}
\hline \multicolumn{1}{|c|}{ Field: Research Areas } & Record Count & \% of 4822 \\
\hline Psychology & 1604 & $33.3 \%$ \\
\hline Computer Science & 1085 & $22.5 \%$ \\
\hline Engineering & 706 & $14.6 \%$ \\
\hline Neurosciences Neurology & 706 & $14.6 \%$ \\
\hline Psychiatry & 444 & $9.2 \%$ \\
\hline Linguistics & 321 & $6.7 \%$ \\
\hline Ophthalmology & 263 & $5.4 \%$ \\
\hline Optics & 235 & $4.9 \%$ \\
\hline Imaging Science Photographic Technology & 211 & $4.4 \%$ \\
\hline Education Educational Research & 167 & $3.5 \%$ \\
\hline
\end{tabular}

\section{Eye Tracking Research on Website Design}

From the perspective of website design the eye tracking technique has plenty of advantages as it may provide a stream of information about the user's mental state in real time and as an objective method which can reflect cognitive processing through eye movement metrics (Wang et al., 2014; Martin et al., 2011; Just \& Carpenter, 1976). Eye tracking related metrics may be modified according to the aim of research and the assumption of tests, especially the tasks performed by users. A detailed analysis of eye tracking metrics applied in different types of research was performed by Jacob and Karn (2003) who compared 21 studies incorporating eye tracking from the point of view of the number of respondents and the tasks they had to accomplish during the research.

The first studies related to human-computer interaction where a real time stream of information on the basis of eye movement was obtained started in the 1980s and they were mostly focused on the needs of disabled users (Levine, 1984; Hutchinson et al., 1989). In the 1990s the development of new information and communications technologies (ICT), especially the Internet, caused the growth of interest in eye tracking as a means of examining the usability of computer interfaces and websites (i.e. Benel et al., 1991; Ellis et al., 1998). Since that time eye tracking on website design has had several streams. Wang and colleagues (2014) distinguished three important types of studies. The first of them includes the research 
about website design elements, e.g. Schmutz et al. (2010) examined the effects of different presentation types (matrix versus list) on cognitive load and consumer decisions; Leuthold et al. (2011) compared the influence of different navigation designs (vertical versus dynamic menus) on user performance. The second type are publications concerning the fixation patterns of the users, e.g. in his study, Nielsen (2006) observed that the dominant reading pattern of 232 users watching thousands of webpages looks like an F shape. The third type of studies is the literature focused on cultural differences in the fixation behavior of the user, e.g. Dong and Lee (2008) compared the behavior of Chinese, Korean, and American users.

\section{Design of Museum Websites}

The issues of design of museum websites are not widely discussed in scientific literature, the query performed in the Web of Science Core Collection gave only 208 publications related to the general topic of museum website design and usability by not necessarily incorporating the eye tracking technique, although there are the research studies which seek to examine the special needs of museum website visitors as a distinctive type of Internet users. Pallud and Straub (2014) identified the variables that play a role and influence online behaviors in a specific experiential environment, namely the high culture museum website. They proposed a research model which was tested on two different websites and provided the basis to assume that: (1) esthetics is the most important design criteria for experiential interfaces and (2) that website design influences the intentions to visit a physical place. Marty and Twidale (2014) conducted 119 scenario-based evaluations of 36 museum websites to develop a conceptual framework for analyzing the usability flaws of museum websites. The aim of this framework is to help the designers of museum websites improve the overall usability of museum websites in general. Skov and Ingwersen (2014) focused on the information searching patterns of online museum visitors. A combination of quantitative and qualitative methods allowed them to identify four main characteristics of online museum visitors' searching behavior: (1) searching behavior has a strong visual aspect, (2) topical searching is predominantly exploratory, (3) users apply broad known item searches, and (4) meaning making is central to the search process. The issue of virtual museum exhibitions has gained special attention from researchers in the available museum research (Sylaiou et al., 2010; Rahim et al., 2011; Yang, 2009). Karoulis and colleagues (2006) conducted a study which intended to assess the usability of the system which offers an enhanced educative and entertaining experience to virtual museum visitors. To this end, they employed two approaches: a questionnaire based survey and a Cognitive Walkthrough session (using eye tracking techniques). This research proves that the web behavior of online museum visitors is an important topic which requires dedicated studies because literature reviews showed some lack of publications concerning this issue.

\section{Information Needs of Museum Website Visitors}

As regards usability of museum websites, it is first of all important to understand why people visit museum websites and what information visitors are looking for on museum web presents. Different groups of website visitors have different information needs; therefore, 
from a museum perspective, it is crucial to provide the required information for specific target groups in the most effective way.

Table 2. Visitor information needs and searching patterns on museum websites (\%)

\begin{tabular}{|c|c|c|c|c|c|}
\hline & Never & Rarely & Occasionally & Frequently & Very often \\
\hline Information about opening hours & 2.9 & 6.5 & 6.2 & 19.1 & 65.3 \\
\hline $\begin{array}{l}\text { Information about museum } \\
\text { location }\end{array}$ & 4.4 & 8.8 & 17.1 & 21.8 & 47.9 \\
\hline Information about ticket prices & 11.2 & 9.4 & 16.7 & 22.1 & 40.6 \\
\hline $\begin{array}{l}\text { Information about current and } \\
\text { future exhibitions }\end{array}$ & 4.4 & 15.3 & 23.5 & 27.4 & 29.4 \\
\hline $\begin{array}{l}\text { Information about museum } \\
\text { events, shows, etc. }\end{array}$ & 10.3 & 19.1 & 30 & 23.5 & 17.1 \\
\hline $\begin{array}{l}\text { Information about educational } \\
\text { activities }\end{array}$ & 53.2 & 22 & 11.5 & 6.8 & 6.5 \\
\hline $\begin{array}{l}\text { Information about museum } \\
\text { collections }\end{array}$ & 50.9 & 22 & 16.8 & 6.5 & 3.8 \\
\hline $\begin{array}{l}\text { Information about museum } \\
\text { history }\end{array}$ & 35 & 37.1 & 14.7 & 10 & 3.2 \\
\hline $\begin{array}{l}\text { Virtual exhibitions and online } \\
\text { tours }\end{array}$ & 43.8 & 25.9 & 18.5 & 10 & 1.8 \\
\hline $\begin{array}{l}\text { Information about museum } \\
\text { publications }\end{array}$ & 64.1 & 21.5 & 9.7 & 3.8 & 0.9 \\
\hline $\begin{array}{l}\text { Information about services, gifts } \\
\text { or coffee shops }\end{array}$ & 60.9 & 21.5 & 13.5 & 3.2 & 0.9 \\
\hline $\begin{array}{l}\text { Archives and museum ongoing } \\
\text { research material }\end{array}$ & 66.8 & 18.5 & 10.9 & 2.9 & 0.9 \\
\hline $\begin{array}{l}\text { Information about museum } \\
\text { administration }\end{array}$ & 87.7 & 7.6 & 2.9 & 0.9 & 0.9 \\
\hline $\begin{array}{l}\text { Information about donation } \\
\text { or membership opportunities }\end{array}$ & 83.5 & 10.3 & 4.7 & 0.6 & 0.9 \\
\hline $\begin{array}{l}\text { Reports about museum and legi- } \\
\text { slation documents }\end{array}$ & 92.3 & 5.3 & 1.5 & 0.3 & 0.6 \\
\hline $\begin{array}{l}\text { Information about employment } \\
\text { or volunteering }\end{array}$ & 83.3 & 9.4 & 4.1 & 2.9 & 0.3 \\
\hline
\end{tabular}

Kravchyna and Hastings (2002) analyzed the audiences of museum websites and identified eight types of people who are using museum web presents:

1. People planning a visit to the physical museum;

2. People who have visited the museum;

3. Educators;

4. Researchers and students; 
5. Curators;

6. Children;

7. Potential visitors who are not able to make a real visit;

8. Managers and donators.

However, the results from the Danish research which was conducted in 2010 show that $80 \%$ of website users primarily use museum websites for preparing a visit to the physical museum. Over half of the users seek information about museum objects, collections or exhibitions (62\%) or museum activities (54\%) (Moos \& Brændholdt Lundgaard, 2010).

In order to understand the habits of Lithuanian museum websites' users and to find out their main areas of interest (concerning the content of museum websites presented in the period of March-May 2014 in Lithuanian national museums), 402 visitors were interviewed on the basis of a questionnaire. The interviews took place at four Lithuanian museums: Lithuanian National Art Museum, National Museum of Lithuania, M.K. Čiurlionis National Museum of Art, and the National Museum - Palace of the Grand Dukes of Lithuania. Research data were collected during all working days of the museums, including weekends. The questionnaires were completed by the interviewer, not by the visitors themselves.

In principle, the research results confirm the results of research of a similar area conducted in other countries: by visiting a museum website the people were in search of the information needed to prepare for a visit to physical museums (Tab. 2). It is obvious that first of all, museum websites are used to find information about opening hours (84.4\% frequently and very often), location (69.7\% frequently and very often), entrance fees $(62.7 \%$ frequently and very often), current exhibitions and events (56.8\% frequently and very often).

By contrast, people search for museum online services or information connected to official procedures of museum activities to a much lesser degree. For example, only $11.8 \%$ of museum website visitors search for information about virtual exhibitions and online tours (by doing it frequently or very often), 3.8\% (frequently or very often) of visitors are interested in museum archives and ongoing research materials. In general, museum website visitors do not show interest in museum commercial offerings, such as publications $(4.7 \%$ frequently and very often) or gifts (4.1\% frequently and very often).

\section{Evaluation of the Website of the National Museum-Palace of the Grand Dukes of Lithuania Using Eye Tracking}

Once the basic information needs of museum website visitors were identified, the evaluation of the website of the National Museum-Palace of the Grand Dukes of Lithuania using eye tracking equipment began. The aim of the research was to determine visitors browsing habits in finding the most important areas of interest and the most relevant information for users, as well to evaluate end user satisfaction and to formulate recommendations on the optimization of the museum website.

As mentioned before, eye tracking is an objective research method which can reflect cognitive processing through eye movement metrics. There are no data about eye tracker based research on museum websites done in Lithuania. The analysis results may contribute to new knowledge about designing successful interfaces for museum websites. What is more, 
the results could be used in a broader field for improving the interfaces and information representation for websites in general.

\subsection{Data collection}

The data were collected by setting a portable eye tracking laboratory inside the museum near the entrance to exhibitions. 100 respondents were tracked; the overall demographic structure of Lithuanian population by gender (male/female) and age (seven groups: $0-18$; 19-24; 25-34; 35-44; 45-54; 55-64; 65+) was maintained. The respondents were placed in front of a laptop with eye tracking equipment (Tobii X2-30 Eye Tracker) mounted and eye tracking software (Tobii Studio 3.2) installed. The second monitor was connected and used for a live preview of respondent's actions. The participants were seated approximately $60 \mathrm{~cm}$ away from the computer monitor. After calibration and before moving to the main tasks the respondents were asked to enter their sex and age. Then, a small exercise was performed, making the respondents comfortable with the system. Each respondent was given one of three tasks: to find the opening hours, the entrance ticket price and the information about exhibitions. The tasks were selected according to the previously presented research results of the information needs of museum website visitors. All tasks were done on the website of the National Museum-Palace of the Grand Dukes of Lithuania by starting the task from the homepage. Research data were collected in June-July 2014.

\subsection{System configuration}

The system was configured to use Tobii recommended I-VT filter. Fixations ${ }^{1}$ were defined as having fixated in a given area for at least $60 \mathrm{~ms}$ (shorter fixations were discarded). The length of fixation is usually an indication of information processing or cognitive activities. Regressive saccades and the saccade pattern can reveal confusion and problem understanding. Vision is largely suppressed during the movement. The end point of a saccade cannot be changed during the movement. A velocity calculator window length was set to $20 \mathrm{~ms}$, gap fill-in length - to $75 \mathrm{~ms}$. Adjacent fixations were set to merge if the maximum time between fixations did not exceed $75 \mathrm{~ms}$ and the angle between fixations was less than 0.5 degree.

\subsection{Eye tracking metrics}

In order to find out the browsing speed and ways to the most important information for users on the website of the National Museum - Palace of the Grand Dukes of Lithuania, a few eye tracking metrics were measured. The first is time to first area of interest fixation. It shows the time for a participant to first fixation on a specific area of interest (AOI). The time to the first fixation is a linear variable counted in milliseconds. Taken on its own, this metric does not reveal much. However, when compared to other areas of interest, the time to the first fixation can show which elements of the page draw the user's attention in the context of the task they are asked to perform. The time to the first fixation was used to

\footnotetext{
${ }^{1}$ Fixations are stops during which the brain starts to process the visual information received from the eyes; fast jumps from one fixation to the other are saccades.
} 
measure task completion time: from the beginning of the test to the moment the user gaze enters AOI (he/she finds the required information). The findings could show that some elements of the page completely unrelated to completing the task compete with those that are related to the task. The number of fixations the participant has on a pre-defined AOI was measured as fixation count. All webpage areas were defined as specific areas of interest.

Gaze plots (a representation of user's eye movement across the screen, fixation by fixation; the size of the gaze plot dot relates to how long a user has fixated on the specific spot) and heat maps (a representation of the different areas of the screen where the user has spent most time looking; green color represents least time focused on an area and red - most time) were generated on the basis of measurements and analyzed.

Figure 1. Homepage sections of the website of the National Museum Palace of the Grand Dukes of Lithuania

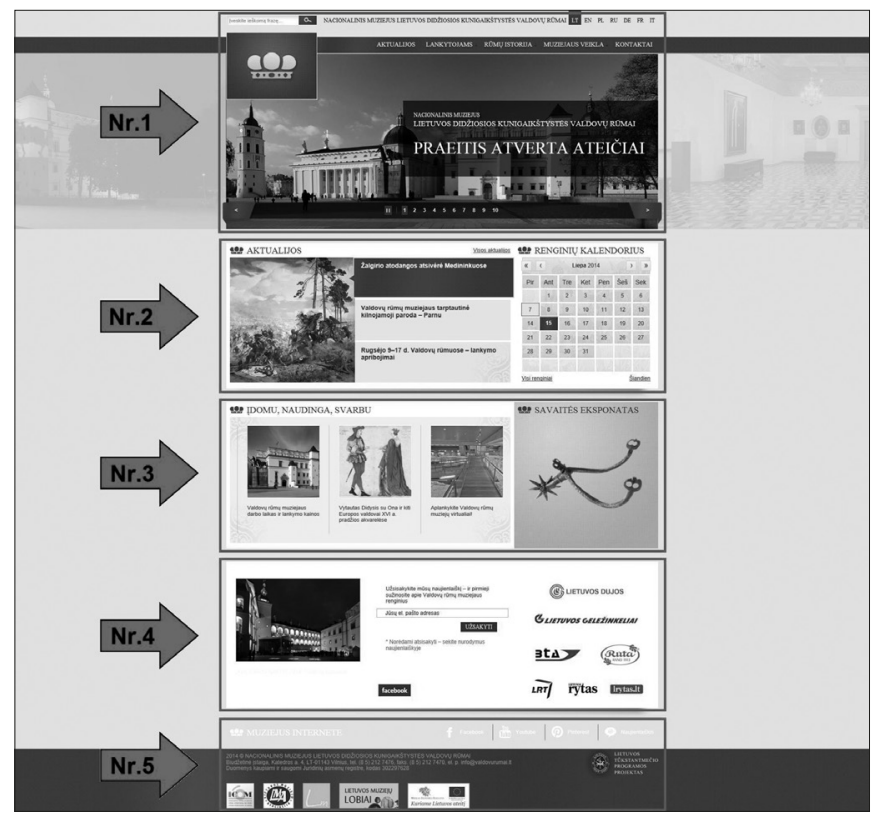

\section{Homepage of the Website of the National Museum - Palace of the Grand Dukes of Lithuania}

The homepage of the website of the National Museum - Palace of the Grand Dukes of Lithuania (Fig. 1) starts from the menu bar at the top (Nr.1) with the language selection bar (a possibility to select Lithuanian, English, Polish, Russian, German, French or Italian languages), the navigation bar (drop down menu lists "News", "Visitor Information", "Palace History", "Activities" and "Contacts") and the changing photo of the museum. The second important part of the homepage is the news bar (Nr.2) with the presentation of three most relevant news of the museum and the events calendar. The third content bar on the 
homepage is designed to present interesting, useful and important information (Nr.3) and the exhibit of the week. The fourth content bar on the homepage of the National Museum Palace of the Grand Dukes of Lithuania is dedicated to the subscription of the electronic newsletter of the museum (Nr.4) and the presentation of its sponsors. The bottom down bar of the museum homepage is designed for page information, social media and other museum project links (Nr.5).

The information about museum opening hours could be found through the first block of the section "interesting, useful, important" of the homepage (Nr.3) or through the menu bar drop down menu lists section "Contacts" (Nr.1). The information about the entrance ticket price was only placed on the first block of the section "interesting, useful, important" of the homepage (Nr.3) or through the menu bar drop down menu lists section "Visitor Information" item "Excursions" (Nr.1). The information about the exhibitions could be found through the menu bar drop down menu lists section "Visitor Information" item "Exhibitions" (Nr.1).

\section{Results}

Average time for users to find the most needed information (opening hours, entrance ticket price and the information about exhibitions) was 36.4 seconds (the shortest task completion time was 5 seconds (women, age group $0-18$ ), the longest time -180.4 seconds (women, age group 45-54)).

Analysis of the data collected by demographic characteristics did not show a significant difference between men and women; however, on the average, women ( 35.5 seconds) completed the task a little bit faster than men (37.3 seconds) (Tab. 3). In both cases the fixation number corresponds directly to the time spent on task completion.

Table 3. Task completion by gender (average)

\begin{tabular}{|l|c|c|}
\hline & Men & Women \\
\hline Time & 37.3 & 35.5 \\
\hline Fixations & 92.9 & 90.1 \\
\hline
\end{tabular}

Analysis of respondents' task completion results by age characteristics shows significantly greater differences (Tab. 4). The best information search task performance time was recorded in the age group 19-24 (19.1 seconds). Above average task performance results were recorded in age groups 0-18 (26.9 seconds), 25-34 (27.7 seconds) and 35-44 (30.8 seconds).

There is an evident connection between the age of the respondents and the time needed to complete the task. The older the person searching for the information on the website of the National Museum - Palace of the Grand Dukes of Lithuania, the more time that person needs. However, the worst task completion results were not recorded in the oldest respondent group 65+ (49.2 seconds), but in the group 55-64 (55.4 seconds). Such a result can be explained by the process of data collection: quite a few people from the age group 
$65+$ refused to take part in the research stating that they did not know how to use the computer in general. Therefore, it can be assumed that the people from the age group 65+ who agreed to take part in the research had above-average computer literacy; that is why the task completion results in this group were better compared to the age group 55-64.

Table 4. Task completion by age (average)

\begin{tabular}{|l|c|c|c|c|c|c|c|}
\hline & $\mathbf{0 - 1 8}$ & $\mathbf{1 9 - 2 4}$ & $\mathbf{2 5 - 3 4}$ & $\mathbf{3 5 - 4 4}$ & $\mathbf{4 5 - 5 4}$ & $\mathbf{5 5 - 6 4}$ & $\mathbf{6 5 +}$ \\
\hline Time & 26.9 & 19.1 & 27.7 & 30.8 & 48.9 & 55.4 & 49.2 \\
\hline Fixations & $\mathbf{6 5 . 3}$ & 47.1 & 70.7 & 77.7 & 131.9 & 136.5 & 118.3 \\
\hline
\end{tabular}

The average fixation number reveals some interesting results. On the one hand, it can be seen that the number of fixations is directly connected to the time spent on searching (longer task performing time equal higher number of fixations) but on the other hand, it is possible to find obvious differences connected to the age of the respondents. For example, age groups 45-54 and 65+ spent almost the same time on task completion (48.9 and 49.2 seconds respectively) but the number of fixations differs significantly. The respondents from the group 45-54 had 131.9 fixations in order to complete the task of finding the required information, while the people from the group 65+ had the average of 118.3 fixations during almost the same time. It is possible to assume that older people need more time to process information from a particular point of attention; however, it does not say anything about the efficiency of the searching process in general because they needed the same time to find information as the people from the group 45-54.

Figure 2. Heat map analysis of the information search on the homepage of the website of the National Museum - Palace of the Grand Dukes of Lithuania

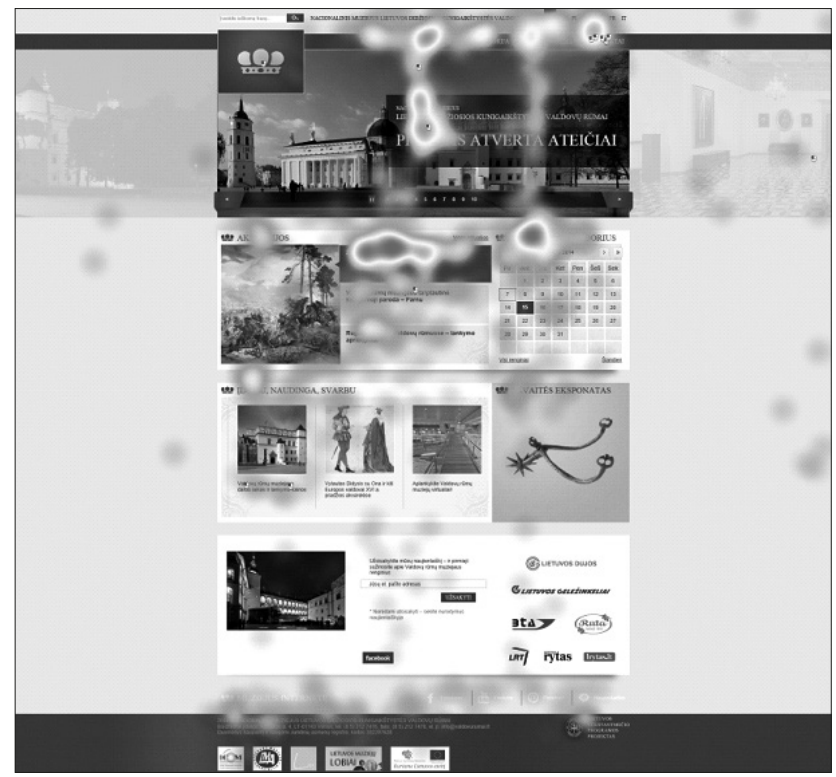


However it is hard to do general conclusions based on collected data, because in the case of an age diversity some groups are on too large scale. Additional analysis needed for a more detailed generalizations concerning the fixation duration dependence on the age of respondents.

The heat map analysis of the data collected (Fig. 2) reveals different areas of the screen where the users spent most time searching for the information on opening hours, ticket prices and exhibitions. The first point of attention was the news bar of the homepage (Nr.2) displaying three most relevant museum news for the majority of respondents in the research, but after the first seconds of browsing most of them moved up to the navigation bar and started searching for the required information on drop down menu lists. Drop down menu sections "Visitor Information" and "Activities" drew most visitor attention during task completion.

The analysis of user's gaze plots uncovered the main problems of information placement on the museum website and revealed the errors of searching the required information made by users. The majority of the users were trying to find the most required information (opening hours, entrance ticket price and the information about exhibitions) on the homepage navigation bar - drop down menu lists. A typical example (Fig. 3) is as follows: it took 95 seconds for a user (man, age group 25-34 years) to find the exit from the homepage to the ticket price page. The user was searching for this information on the top menu and in the central part of the page but he failed to notice a hyperlink "Opening hours and visiting prices" (Fig. 3; marked by the red arrow in the red rectangle). Finally, he found another way by browsing the drop down menu lists section "Visitor Information" and selecting "Excursions" from the menu.

Figure 3. Typical gaze plot analysis of the homepage of the National Museum-Palace of the Grand Dukes of Lithuania (man, age group 25-34)

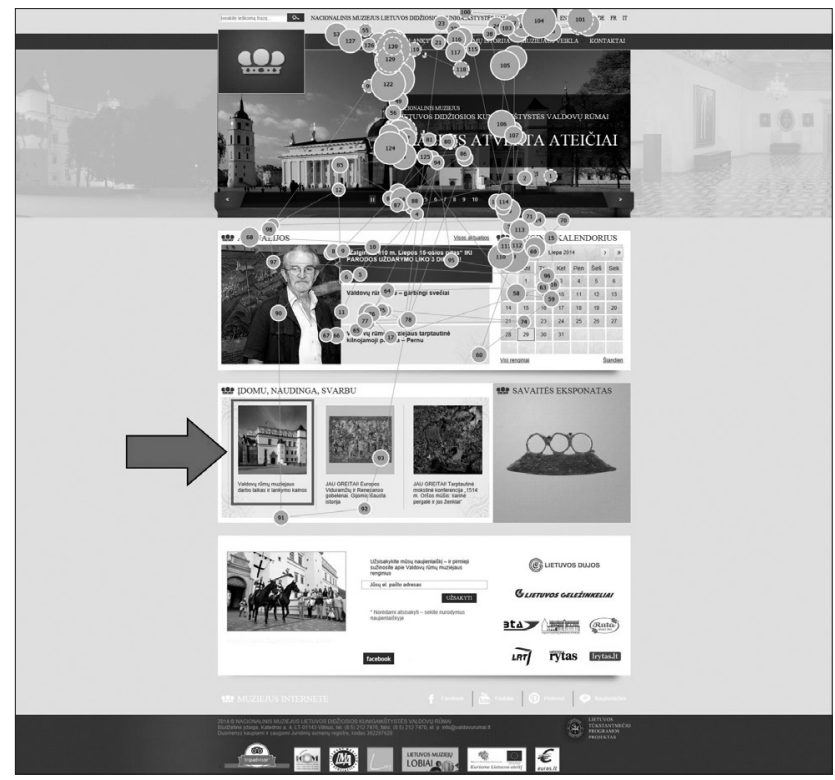




\section{Conclusion}

The use of eye tracking in different types of usability research areas has shown an upward trend worldwide in recent years. Being an objective research method with the possibility of reflecting cognitive processing through eye movement metrics, eye tracking is widely used in psychology, computer sciences, engineering, human-computer interaction, website usability and many other fields. However, the issues of museum website design and usability research using eye tracking techniques and methods have not so far been widely discussed in scientific literature.

Eye tracking could be a useful tool for museums and other cultural institutions for improving their web presents and making their websites more attractive to visitors. However, eye tracking cannot be used as the only method for improving website usability. Other measures and methods must be used in addition to eye tracking.

The research of the information needs of the visitors of Lithuanian museum websites revealed the most required information: opening hours, museum location, entrance ticket price and information about exhibitions. The results allow us to confirm the assumption that people use museum websites as a primary tool to prepare for a visit to the physical museum.

With these facts in mind, it is recommended for museums to place the most required information for users on their homepage and make it clearly visible as well as easy to find. The example of the eye tracking analysis of the website of the National Museum - Palace of the Grand Dukes of Lithuania revealed the typical mistakes and errors made in placing information: (1) most important information placed in different places and levels of the website, what causes the problems for user to find needed information; (2) graphic design solutions of information presentation are not suitable because users do not notice important information.

When the information which is most needed for users is placed in different locations and levels of the website, it takes more time and efforts for visitors to find the information and to prepare for a visit to the museum. However even information placing on the first level of the website requires an appropriate solutions, otherwise users simple can skip it and have lower satisfaction.

\section{References}

Benel, D.C.; Ottens, D.; Horst, R. (1991). Use of an eye tracking system in the usability laboratory. Proceedings of the Human Factors Society 35th Annual Meeting, 461-465.

Cooley, R. (2003). The use of Web Structures and Content to Identify Subjectively Interesting Web Usage Patterns. ACM TOIT, 3(2), 93-116.

Dong, Y.; Lee, K. (2008). A cross-cultural comparative study of users' perceptions of a webpage: with a focus on the cognitive styles of Chinese, Koreans and Americans. International Journal of Design, 2(2), 19-30.

Duchowski, A. T. (2007). Eye Tracking Methodology: Theory and Practice. Secaucus, NJ, USA: Springer-Verlag New York, Inc.

Ellis, S.; Candrea, R.; Misner, J.; Craig, C.S.; Lankford, C.P.; Hutshinson, T.E. (1998). Windows to the soul? What eye movements tell us about software usability. Proceedings of the Usability Professionals' Association Conference 1998, 151-178.

Fitts, P.M.; Jones, R.E.; Milton, J.L. (1950). Eye movements of aircraft pilots during instrument-landing approaches. Aeronautical Engineering Review, 9(2), 24-29. 
Gibson, E.J. (1941). Retroactive inhibition as a function of degree of generalization between tasks. Journal of Experimental Psychology, 28(2), 93-115.

Heijden, A. H. C., van der (1991). Selective attention in vision. London: Routledge.

Helmholtz, H., von (1925). Treatise on Physiological Optics. New York: Optical Society of America. Huey, E. B. (1908). The Psychology and Pedagogy of Reading. New York: The MacMillan Company.

Hutchinson, T.E.; White, K.P.; Martin, W.N.; Reichert, K.C.; Frey, L.A. (1989). Human-computer interaction using eye-gaze input. IEEE Transactions on Systems, Man, and Cybernetics, 19, 1527-1534.

ISO. (1998). ISO 9241: Ergonomics Requirements for Office Work with Visual Display Terminal (VDT) - Part 11: Guidance on usability.

Jacob, R.; Karn, K.S. (2003). Commentary on Section 4 - Eye Tracking in Human-Computer Interaction and Usability Research: Ready to Deliver the Promises. In: J. H. R. Deubel (ed.), The Mind's Eye. Amsterdam: North-Holland, 573-605.

Just, M.A.; Carpenter, P.A. (1976). Eye fixations and cognitive processes. Cognitive Psychology, 8(4), 441-480.

Karoulis, A.; Sylaiou, S.; White, M. (2006). Usability Evaluation of a Virtual Museum Interface. INFORMATICA, 17(3), 1-17.

Kravchyna, V.; Hastings, S.K. (2002). Informational Value of Museum Web Sites. First Monday [online], 7(2), [29.09.2014], http://journals.uic.edu/ojs/index.php/fm/article/view/929/851.

Leuthold, S.; Schmutz, P.; Bargas-Avila, J.A.; Tuch, A.N.; Opwis, K. (2011). Vertical versus dynamic menus on the world wide web: Eye tracking study measuring the influence of menu design and task complexity on user performance and subjective preference. Computers in Human Behavior, 27(1), 459-472.

Levine, J.L. (1984). Performance of an eyetracker for office use. Computational Biology and Medicine, $14,77-89$.

Martin, C.; Cegarra, J.; Averty, P. (2011). Analysis of Mental Workload during En-route Air Traffic Control Task Execution Based on Eye-Tracking Technique. In: D. Harris (ed.), Springer Berlin Heidelberg, 592-597.

Marty, P.; Twidale, M. (2004). Lost in gallery space: A conceptual framework for analyzing the usability flaws of museum Web sites. First Monday, [online], 9(9), [29.09.2014], http://firstmonday.org/ojs/ index.php/fm/article/view/1171/1091

Matera, M.; Rizzo, F.; Carughi, G. (2006). Web Usability: Principles and Evaluation Methods. In: E. Mendes \& N. Mosley (eds.), Springer Berlin Heidelberg, 143-180.

Moos, T.; Brændholdt Lundgaard, I. (2010). The Museum's Web Users - A User Survey of the Museums' Websites. Heritage Agency of Denmark, [online], [29.09.2014], http://www.kulturstyrelsen. $\mathrm{dk} /$ fileadmin/publikationer/publikationer_engelske/Reports/The_museum_s_web_users_2010.pdf

Nielsen, J.; Mack, R. L. (1994). Usability Inspection Methods. New York: Wiley.

Nielsen, J. (1993). Usability Engineering. Cambridge, MA: Academic Press.

Nielsen, J. (2006). F-shaped pattern for reading web content [online]. Nielsen Norman Group, [29.06.2015], http://www.nngroup.com/articles/f-shaped-pattern-reading-web-content/

Nielsen, J. (2012). Usability 101: Introduction to Usability [online]. Nielsen Norman Group, [29.06.2015], http://www.nngroup.com/articles/usability-101-introduction-to-usability/

Nielsen, J.; Pernice, K. (2009). Eyetracking Web Usability (1st ed.). Thousand Oaks, CA, USA: New Riders Publishing.

Pallud, J.; Straub, D.W. (2014). Effective website design for experience-influenced environments: The case of high culture museums. Information IE Management, 51(3), 359-373.

Polson, P.; Lewis, C.; Rieman, J.; Wharton, C. (1992). Cognitive Walkthrough: A Method for Theory-based Evaluation of User Interfaces. International Journal of Man-Machine Studies, 36, 741-773.

Rahim, N.; Wook, T.S.M.T.; Zin, N.A.M. (2011). Developing Conceptual Model of Virtual Museum Environment Based on User Interaction Issues. Visual Informatics: Sustaining Research and Innovations, Pt Ii, 7067, 253-260. 
Schmutz, P.; Roth, S.P.; Seckler, M.; Opwis, K. (2010). Designing product listing pages-Effects on sales and users' cognitive workload. International Journal of Human-Computer Studies, 68(7), 423-431.

Senders, J.W. (2000). Four theoretical and practical questions. Keynote address presented at the Eye Tracking Research and Applications Symposium. Proceedings of the Eye Tracking Research and Applications Symposium 2000, 8.

Skov, M.; Ingwersen, P. (2014). Museum Web search behavior of special interest visitors. Library E Information Science Research, 36(2), 91-98.

Sylaiou, S.; Mania, K.; Karoulis, A.; White, M. (2010). Exploring the relationship between presence and enjoyment in a virtual museum. International Journal of Human-Computer Studies, 68(5), 243-253.

Wang, Q.; Yang, S.; Liu, M.; Cao, Z.; Ma, Q. (2014). An eye-tracking study of website complexity from cognitive load perspective. Decision Support Systems, 62, 1-10.

Wharton, C.; Rieman, J.; Lewis, C., et al.Polson, P. (1994). The Cognitive Walkthrough Method: A Practitioner's Guide. In: J. Nielsen \& R. L. Mack (eds.), Usability Inspection Methods. New York: Wiley, 105-140.

Yang, G. (2009). A Study on the User-Centered Interface Design for Virtual Museums. 10th IEEE International Conference on Computer-Aided Industrial Design and Conceptual Design, 1647-1651.

Yarbus, A. L. (1967). Eye Movements and Vision. New York: Plenum.

\title{
Badanie użyteczności serwisów internetowych oparte na eye-trackingu. Studium przypadku witryny internetowej Litewskiego Muzeum Narodowego
}

\begin{abstract}
Abstrakt
Cel/teza: Celem artykułu jest analiza użyteczności serwisu internetowego Litewskiego Muzeum Narodowego-Zamek Dolny w Wilnie z wykorzystaniem techniki Eye Tracking. Badania przeprowadzono z punktu widzenia procesów wyszukiwania informacji realizowanych przez użytkowników serwisu. Koncepcja/metody badań: Do opracowania stanu wiedzy na temat metod oceny użyteczności oraz historycznego ujęcia badań percepcją wzrokową wykorzystano metodę analizy i krytyki piśmiennictwa. Kwestionariusz ankiety był narzędziem zbierania danych na temat potrzeb informacyjnych odwiedzających muzeum oraz stosowanych przez nich schematów wyszukiwania informacji. Technikę Eye Tracking wykorzystano do oceny serwisu internetowego Litewskiego Muzeum NarodowegoZamek Dolny w Wilnie.

Wyniki i wnioski: Technika Eye Tracking cieszy się zainteresowaniem w wielu obszarach badawczych, jednak w kontekście projektowania serwisów informacyjnych muzeów oraz oceny ich użyteczności nie poświęcono jej wiele uwagi w piśmiennictwie naukowym. Wyniki badań nad potrzebami informacyjnymi użytkowników serwisów informacyjnych muzeów litewskich wskazują, że do najbardziej poszukiwanych treści należą: godziny otwarcia, lokalizacja muzeum, ceny biletów oraz informacje o ekspozycjach. Uzyskane wyniki potwierdzają tezę, że użytkownicy serwisów internetowych muzeów wykorzystują je jako narzędzie do przygotowywania się do wizyty w ich fizycznej lokalizacji. Wykorzystanie techniki Eye Tracking do analizy interakcji użytkowników z serwisem internetowym Muzeum Narodowego-Zamek Dolny w Wilnie pokazało typowe błędy projektantów związane z rozmieszczeniem informacji. Jeśli pożądane przez użytkowników informacje zostaną rozmieszczone w serwisie w różnych miejscach i poziomach dostępności, to zwiększa się czas i potrzebny wysiłek do ich lokalizacji.
\end{abstract}


Oryginalność/wartość poznawcza: Zagadnienia projektowania serwisów internetowych muzeów nie są często podejmowanym problemem badawczym w światowej literaturze naukowej. Brakuje również danych badawczych na temat wykorzystania techniki Eye Tracking w ocenie użyteczności serwisów internetowych muzeów na Litwie. Wyniki badań mogą być wykorzystane do projektowania efektywnych interfejsów użytkownika w serwisach internetowych muzeów. W szerszym kontekście wyniki badań mogą mieć zastosowanie w optymalizacji interfejsów i reprezentacji informacji w serwisach internetowych.

\section{Słowa kluczowe}

Badanie użyteczności serwisów internetowych. Eye Tracking. Serwisy internetowe muzeów. Potrzeby informacyjne.

Dr ANDRIUS ŠUMINAS is Head of Media Research Lab at the Faculty of Communication, Vilnius University. He holds a PhD in Information and Communication Sciences. He is a scientific editor of the peer-reviewed scientific journal Parliamentary Studies. His main areas of research are web usability, interactive networking, business communication in social media, political communication, media transformation.

Dr ARÜNAS GUDINAVIČIUS is currently a lecturer and researcher at the Institute of Book Science and Documentation at Faculty of Communication, Vilnius University. Since 1999 he has been working in one of Lithuania's leading digital publishing houses. In 2012 he completed his PhD in Information and Communication Sciences. His research interests are human-computer interaction, digital books and digital publishing.

Contact to the authors:

andrius.suminas@kf.vu.lt

Mediju tyrimu laboratorija, Komunikacijos fakultetas, Vilniaus Universitetas

Sauletekio al. 9, I rūmai

10222 Vilnius, Lithuania 